\title{
R. Rheeder
}

\section{BAAT AS BIO-ETIEK SONDER GRENSE: 'N GEREFORMEERD- ETIESE BEOORDELING VAN ARTIKEL 4 VAN DIE UNIVERSELE DEKLARASIE VIR BIO-ETIEK EN MENSEREGTE VAN UNESCO}

\section{ABSTRACT}

Article 4 of the UNESCO Declaration of Bioethics and Human Rights (2005) is explained as being an ethical principle and right aimed at the health environment. Benefit is defined as good deeds towards people within the medical environment and is accepted as part of universal ethics. This principle means that the person on the one hand has a right to benefit, while on the other hand has the duty to show benefit. To display benefit to mankind is to confirm the dignity of man. From a Christian perspective, the right and ethical principle of benefit is grounded in the creation, re-creation and eschatology. Man as the image of God - as a changed man in Christ - is led by the Spirit to show benefit as love to all people within the health environment.

\section{INLEIDEND}

Artikel 4 van die Universele deklarasie van bio-etiek en menseregte (UDBM) lees soos volg (vgl. UNESCO 2006):

In applying and advancing scientific knowledge, medical practice and associated technologies, direct and indirect benefits to patients, research participants and other affected individuals should

Prof Riaan Rheeder, Faculty of Theology, North-West University, South Africa. E-mail: Riaan.Rheeder@nwu.ac.za 
be maximized and any possible harm to such individuals should be minimized.

Volgens Pellegrino (2009:99) handel artikel 4 van die UDBM se "benefits" en "harm" oor die algemeen erkende bio-etiese beginsels van baat (beneficence) en benadeel (non-maleficence). In hierdie artikel gaan baat, soos dit uitdrukking vind in artikel 4 van UDBM, ondersoek word. Sommige etici hanteer baat en nadeel as een beginsel (Frankena), terwyl ander dit as twee beginsels beskou (Beauchamp \& Childress). Douma $(1997: 87)$ is waarskynlik korrek as hy meen dat daar nie skerp onderskeid tussen die twee beginsels getref moet word nie.

Waarom die ondersoek? In die jaar 2005 is die UDBM eenparig deur al die lidlande van United Nations Educational, Scientific and Cultural Organization (UNESCO) aanvaar (UNESCO 2005). Dit is die eerste en enigste teks op die gebied van die bio-etiek waartoe al die lande van die wêreld hulle verbind het. Daardeur erken die wêreldgemeenskap, en ook Suid-Afrika (UNESCO 2005), die bestaan van universele fundamentele etiese beginsels op die terrein van die bio-etiek (Ten Have 2011:69,75). Die etiese probleem is dat hierdie spesifieke teks (en menseregtebeginsel) en betekenisnuanse soos verstaan binne UNESCO nog nie vanuit 'n Gereformeerde teologiese tradisie beoordeel is nie. Omdat hierdie dokument buite die kerk ontstaan het, voer die Gereformeerde etikus en menseregtekenner JM Vorster (2011:81) aan dat die beginsel Christelik begrond moet word sodat "Christene vrede kan hê ... en ... [dit] vanuit die Christelike geloofsperspektief ondersteun as 'n kernwaarde". Sover vasgestel kon word, het die breë gereformeerde tradisie ook nie direk deel gehad aan die opstel van die dokument nie. Die sentraal teoretiese argument in hierdie studie is dat baat as beginsel en mensereg in Artikel 4 van die UDMB Gereformeerd-Christelik begrond kan word en daarom as plig uitgevoer moet word. Alhoewel die teoretiese argument gestel word, moet die konklusie van hierdie artikel nie as 'n finale antwoord beskou word nie, maar eerder verstaan word as 'n hulp aan die leser ter vorming van 'n eie ja- of nee-antwoord (Douma 1997:57).

Die idee om binne gesondheidsorg iemand ten baat te wees, is 'n antieke beginsel. Die bekendste verwysing na baat binne die gesondheidsorg word in die Hippokratiese werk Epidemics (ca $410 \mathrm{vC}$ ) gevind waar daar gelees word: "As to disease, make a habit of two things - to help, or at least to do no harm." (Beauchamp \& Childress 2009:207). Beauchamp (2008:5) is van mening dat daar binne die gesondheidsorg waarskynlik nie 'n groter beginsel as baat is nie. 


\section{BAAT AS MENSEREGTE-BEGINSEL}

\subsection{Baat en menswaardigheid}

Pellegrino (2009:100) is van mening dat die direkte verband tussen artikels 3 en 4 in UDBM nie stilswygend aanvaar kan word nie. Sonder twyfel word die etiese beginsel asook die afgeleide reg van baat gegrond in die menswaardigheid van die mens. In 'n UNESCO-dokument, wat die ontwikkeling en denke agter die UDBM verduidelik, word die noue verband tussen menswaardigheid en baat bevestig (Explanatory Memorandum on the Elaboration of the Preliminary Draft Declaration on Universal Norms on Bioethics 2005 par. 12):

A most important achievement of the draft declaration is that it anchors the principles that it espouses firmly in the rules governing human dignity, human rights and fundamental freedoms.

Menswaardigheid dui op die besondere status van die mens. Daarom is Pellegrino (2009:101) korrek as hy aanvoer dat, uit hierdie status van die mens, die etiese verantwoordelikheid teenoor die ander mens afgelei word. Omdat die agent menswaardig is, hy die plig om baat te toon. Maar ook, omdat die ander mens menswaardig is, moet baat aan die ander mens betoon word. Die etiese beginsel van baat gee uitdrukking aan die waarde van die mens. Pellegrino (2009:101) stel dit soos volg:

Inherent dignity is the property of being human that generates the universal moral obligations to do good for, and avoid harm to, other humans.

Bostaande beredenering word bevestig deur artikel 2 van die UDBM wat stel dat die doelwit van die deklarasie onder andere is "... to provide a universal framework of principles" met die spesifieke doel om "to promote respect for human dignity" (UNESCO, 2006). Deur binne die gesondheidsomgewing baat te bewys word respek vir menswaardigheid betoon.

\subsection{Baat as begrip}

Die Afrikaanse woord baat is die vertaling van die Engelse woord "beneficence" en beteken dat die mens 'n opdrag het om by te dra tot die welstand van sy medemens. Baat is alle vorme van goeie dade wat die welstand of belange van die ander mens bevorder of verbeter (Cullity, 2007:19, 21; Beauchamp \& Childress 2009:197). Baat is goeie dade verrig (Pellegrino 2009:101) of "doing good" binne die gesondheidsomgewing 
(Verhey 2011:96) wat die goeie vir die betrokke mens laat toeneem (Frankema 1963:37).

Die UDBM beskou baat as 'n beginsel wanneer artikel 2 van die UDBM dit soos volg stel (UNESCO 2006):

The aims of this Declaration are: (a) to provide a universal framework of principles and procedures to guide States in the formulation of their legislation, policies or other instruments in the field of bioethics; (b) to guide the actions of individuals, groups, communities, institutions and corporations, public and private.

Beauchamp and Childress (2009:12-13) verstaan 'n beginsel as 'n breë analitiese raamwerk of vertrekpunt waaruit die reg of verkeerd van 'n handeling bepaal word. 'n Handeling word gemeet aan beginsel. Beginsels dien as algemene riglyne vir die vorming van meer besondere reëls of norme. Reëls of norme wat op die beginsel steun, is meer presies en vorm praktiese riglyne wat die beginsel verskerp (vgl. ook Vorster, 2007:9-11). Uit die beginsel van baat word die volgende reëls of norme (as goeie dade) geregverdig en afgelei-volgens Douma (1997:83) geïnterpreteer, gespesifiseer en uitgebalanseer - wat binne die gesondheidsomgewing toegepas kan word en wat sonder twyfel ook binne die UDBM veronderstel word (Beauchamp, 2008:5; Beauchamp \& Childress 2009:13,199; Pellegrino 2009:102):

- Beskerm en verdedig die regte van die mens (reg op gesondheid),

- Voorkom skade in vorm van siekte en gestremdheid aan die mens (voorkomend; inenting),

- Verlig of verminder skade aan die mens (versag siekte; verlig pyn),

- Verwyder toestande wat die mens skade sal aandoen (genesing),

- Help die mens wat gestremd is,

- Red die mens in gevaar,

- Balanseer voordele, nadele en koste ten opsigte van die mens.

Dit is ook belangrik om daarop te wys dat UNESCO (2008) in sy amptelike verklaring van die UDBM, naamlik Curriculum Section 1: Syllabus Ethics Education Programme die volgende norme byvoeg:

- Verbetering (enhancement),

- Psigologiese baat. 
In aansluiting by die bepaling van die begrip baat, onstaan die vraag rakende die omvang van baat. In hierdie verband word die volgende drie opmerkings gemaak.

Eerstens word ook die vraag gestel of baat binne die gesondheidsomgewing eksklusief gerig is op genesing en verwante aktiwiteite soos versorging, voorkoming en verwydering van siektes en sluit dit enige ander vorm van baat soos voorbehoeding, kosmetiese ingrepe, dokter-ondersteunde selfdoding uit? Sou in vitro-bevrugting in die behandeling van onverklaarbare infertiliteit as baat beskou kan word? Die rede waarom sommige gesondheidswerkers en etici van mening is dat die behandeling van fertiliteit nie as baat beskou kan word nie, is dat hulle welstand (gesondheid) beskou as die afwesigheid van siekte.

However, conceding this point does not move us far from the disease model of health in that the range of health benefits is still exhausted by either the treatment or the avoidance of disease (UNESCO 2008).

Daar word aanvaar dat egpare met onverklaarbare infertiliteit nie regtig siek is nie en dat infertiliteit nie 'n siektetoestand is nie. In vitro-behandeling word beskou as die behandeling van kinderloosheid en nie van'n siekte nie, want die behandeling laat die egpaar steeds infertiel. Beide UNESCO in 'n amptelike tweede dokument wat die UDBM verklaar naamlik Bioethics Core Curriculum Section 2: study materials ethics education programme (UNESCO 2011) en Beauchamp (2008) is van mening dat die behandeling van infertiliteit as ' $n$ vorm van baat binne die gesondheidsomgewing beskou moet word en dat infertiliteit as 'n gesondheidsbehoefte of -gebrek verstaan moet word.

Daar word in die algemeen erken dat infertiliteit die bron is van groot hartseer en spanning is wat lyding vir egpare meebring. Op 'n persoonlike vlak is 'n lewe in 'n familie en die grootmaak van kinders vir egpare 'n wesenlike element van emosionele gesondheid of welstand en maak deel uit van sosiale aanvaarding. Daar moet egter rekening gehou word daarmee dat nie-siekteverwante toestande in die algemeen as deel van medisyne en geneeskunde behandel word. Hier word gedink aan die herstel van liggaamlike disfunksionering deur trauma soos gebreekte bene en breinbeserings. Binne die geneeskunde word soms nog verder gegaan as bloot die herstel van liggaamlike funksie, naamlik in die aanbieding van prosteses. Laasgenoemde kan beskou word as die behandeling van 'n sosiale disfunksie en niemand sal ontken dat dit inderdaad 'n daad van baat binne die gesondheidsomgewing is nie (UNESCO 2008). Aansluitend hiermee is die verdere doel van baat om die mens in staat te stel om voort te gaan met die verhoudings waarin hy of sy staan (Cullity 2007:22). Sonder twyfel is dit ook waar dat infertiliteit as 'n gesondheidsbehoefte nie by alle 
egpare sal voorkom nie en dat die lewenskonteks bepaal of dit 'n nood is al dan nie (vgl. UNESCO 2011).

In die lig van bogenoemde is dit begryplik dat baat binne gesondheid 'n fisiese en psigologiese (en sosiale) gerigtheid het. In hierdie verband kan verwys word na Curriculum Section 1: Syllabus Ethics Education Programme wat hierdie waarheid soos volg verwoord (UNESCO 2008):

Even though there has been vigorous debate amongst psychiatrists and philosophers about the application of terms like "illness" to mental conditions, it is generally accepted that many behaviours and psychological phenomena fall under the umbrella of health.

In hierdie sin kan saamgestem word dat, met die amptelike verklaring van UNESCO, baat in artikel 4 van die UDBM nie alleen op die fisiese gerig is nie, maar ook die psigologiese welstand van die mens insluit.

Daar bestaan egter ook ' $n$ probleem met betrekking tot bogenoemde verstaan van baat binne die gesondheidsomgewing. Die WHO definieer gesondheid as "a state of complete physical, mental, and social wellbeing and not merely the absence of disease or infirmity". Hierdie definisie neem in ag dat die beperking van gesondheid tot (liggaamlike) siekte 'n te beperkte definisie is. Hierteenoor wil hierdie definisie erns maak met die psigologiese en sosiale aspekte van gesondheid, maar hierdie wye verstaan bring mee dat die owerheid by implikasie vir te veel sake verantwoordelik gehou sal word. Die uitgebreide definisie beteken onder andere, dat die volgende sake onder baat ingesluit kan word: finansiële ondersteuning, die verkryging van toegang tot gesondheidsorg, voorsiening van omvattende verdedigingsmiddele om die sekuriteit van burgers van 'n land te verseker en deur voorsiening van onderwys (Beauchamp 2008:5; UNESCO 2008). UNESCO (2008) erken die probleem en stel die volgende voor ter oplossing van die probleem:

So how do we proceed when we want to identify a health benefit? General definitions of health tend to be either too wide or too narrow to fit all cases to be of much assistance. It might therefore be helpful to look at the arguments that have been made for and against the identification of a particular condition as a candidate for being a health need and for the identification of the relevant concomitant health benefits attaching to the treatment of that condition.

Daar is reeds bepaal dat gesondheidswerkers 'n besliste plig van baat het teenoor pasiënte. In die tweede plek ontstaan die vraag, naamlik hoe ver strek die plig van baat binne die bestaan van bepaalde verhoudings. Beauchamp en Childress (2009:205) konkretiseer hierdie probleem met die volgende vraag: "Are physicians and other health care professionals 
obligated to accept extraordinary risks while caring for abusive or contagious patients?"

Pellegrino (2009:102) is van oordeel dat baat impliseer dat 'n groter mate van selfbelang onderdruk moet word, omdat die gevaar van infektering, tyd en inkomsteverlies asook persoonlike steurnis 'n volstrekte realiteit is. Beachamp en Childress (2009:198-201) is van mening dat baat nie noodwendig heldhaftige dade insluit nie, omdat die gesondheidswerker in die eerste plek nie 'n filantroop of altruïs is van wie buitengewone tyd, geld en risiko verwag word nie. Die inhoud van die baat word gewoonlik binne 'n bepaalde omgewing kontraktueel bepaal (vgl. ook Douma 1997:89-90). Daarom kan optrede nie van die gesondheidwerker verwag word wat ernstige risiko's, koste of laste tot gevolg sal hê nie. Wettige selfbelang soos familie en persoonlike pligte moet duidelik in ag geneem word.

Dit is belangrik om op te merk, derdens, in aansluiting by Beauchamp en Childress (2009:197-198), dat die beginsel van baat nie as die enigste etiese beginsel beskou moet word nie. Die utilitarisme en Kantianisme is monisties in die sin dat baat of die kategoriese imperatief as die uitsluitlike premis van moraliteit beskou word (Douma 1997:82), wat alle ander beginsels regverdig, of wat alle ander beginsels ophef. Hierteenoor, "It is one among a number of prima facie principles, and it does not determine the overall balance of moral obligations". Voorgaande aanhaling vat ook die uitgangspunt van die UDBM saam wat artikel 4 as een beginsel binne ' $n$ verskeidenheid ander beginsels (art. 5-17) erken. Hierdie beginsel in die UDBM moet in samehang met al die ander beginsels verstaan word (sien art. 261). Die implikasie van hierdie feit is dat die beginsel van baat deur ander beginsels aangevul of beperk kan word.

\subsection{Baat as plig}

Die beginsel van baat dui op 'n morele verpligting (' $n$ moet) om tot fisiese en psigiese voordeel van die ander mens op te tree (vgl. ook Cullity, 2008:19) deur hulle belange te bevorder, asook die voorkoming en verwydering van moontlike fisiese en psigiese skade. Dit beteken dat die morele mens nie 'n keuse het of hy of sy aan die ander mens goed wil doen nie, maar is gebind tot baat (Douma 1997:83). Baat moet oorgaan tot die daad. Volgens hierdie etiese beginsel is die morele mens verplig om goed aan die ander mens te bewys (Frankema 1963:37). Soos die Priester en Leviet, mag 'n

1 "This Declaration is to be understood as a whole and the principles are to be understood as complementary and interrelated. Each principle is to be considered in the context of the other principles, as appropriate and relevant in the circumstances" (UNESCO 2008). 
mens nie die ander mens se belange ignoreer nie, maar moet positief soos die Barmhartige Samaritaan (oorgaan tot) iets doen om die situasie van die ander mens te verbeter (Pellegrino 2009:102).

Dit is belangrik om hier daarop te let dat die UDBM nie die vraag beredeneer of daar inderdaad so 'n universele plig bestaan of nie, maar eenvoudig uitgaan van die standpunt dat daar 'n universele morele plig bestaan om binne die gesondheidsomgewing baat aan die ander mens te betoon. Die deklarasie stel duidelik in artikel 4 dat "benefits... should be maximized..." (UNESCO 2006). Hierdie taal dui daarop dat baat as 'n plig beskou word.

Cullity (2008:19-20) voer aan dat, alhoewel die mens 'n plig het om aan die ander mens baat te betoon, kan hierdie plig diskresionêr verstaan word. Ook Beauchamp en Childress (2009:199) is van oordeel dat die mens eties uitdruklik verbied word om enige mens skade aan te doen, maar dit is wel moreel toelaatbaar om nie alle mense altyd ten bate te wees nie. Baat sluit die werklikheid van diskresie in, naamlik wanneer en teenoor wie baat betoon moet word. Feitlik alle mense is dit eens dat alle mense verplig is tot ' $n$ daad van baat teenoor mense met wie daar ' $n$ verhouding bestaan soos kinders, familie, vriende, asook mense wat jou verantwoordelikheid geword het soos 'n professionele verhouding tussen dokter, verpleër en pasiënt (Beauchamp \& Childress 2009:200). Bepaalde verhoudings bring logies gesproke verantwoordelikhede en verwagtinge mee.

In presenting yourself to others as a practitioner of one of these professions, you present yourself as offering to serve these aspects of their welfare, and this gives them an entitlement to expect that you will do so conscientiously (Cullity, 2008:20, 22).

Alhoewel die optimalisering van baat beteken dat baat onderskeidend of selektief toegepas moet word, moet daar egter ook gestel word dat baat soms ook nie-onderskeidend, buite'n 'n bepaalde verhouding, 'n professionele omgewing ook 'n definitiewe plig is. So het die mens die plig, in die konteks van minimale risiko, om iemand te red. Hierteenoor besit ' $n$ verpleegster nie die morele diskresie of hy of sy 'n pasiënt wil ten baat wees of nie. Wanneer 'n verpleegster nie 'n pasiënt ten baat is nie, is haar optrede moreel verkeerd (Cullity 2008:20).

Dit is duidelik dat die UDBM nie gerig is op baat teenoor alle mense nie (soos ander menseregte-instrumente), maar is spesifiek gerig op die gesondheidsomgewing (vgl. ook Pellegrino 2009:102). Artikel 4 stel dit duidelik dat 
In applying and advancing scientific knowledge, medical practice and associated technologies, direct and indirect benefits to patients, research participants and other affected individuals should be maximized... (UNESCO 2006).

\subsection{Baat begrond}

Hoe begrond die UDBM baat as etiese beginsel en mensereg? Beauchamp en Childress (2009:2-3, 198-200) is van mening dat baat deel uitmaak van die algemene moraliteit (common morality), wat beteken dat feitlik alle mense saamstem dat baat ' $n$ definitiewe plig is, soos feitlik alle mense erken dat moord oneties is:

The common morality is the set of norms shared by all persons committed to morality...In its most familiar sense, morality refers to norms about right and wrong human conduct so widely shared that they form a stable social agreement.

Algemene (universele) moraliteit is dus 'n produk van menslike ervaring en geskiedenis wat in alle kulture aangetref word, maar wat uiteindelik ook alle kulture transendeer. Vorster (2004:85) haal Simkhada aan wat aanvoer:

Whatever religion, culture, part of the world we belong to, the human experience is one of a universal quest for dignity and mutual respect.

Algemene moraliteit vorm normatiewe krag. Volgens Beauchamp en Childress (2009:4) bestaan die moontlikheid dat algemene norme empiries vasgestel kan word. Douma (1997:83) beskryf hierdie "common morality" soos volg: "Het gaan in die algemene moraal om universele standaards, te vergelijken met die universele mensenrechten".

Douma (1997:84) twyfel egter aan die bestaan van 'n algemene moraal. Hierteenoor is die bestaan van die UDBM 'n duidelike bewys van gedeelde moraliteit. Tydens die ontwikkeling van die UDBM het die IBC2 in Augustus 2004 openbare verhore gehou waar godsdienstige verteenwoordigers (uit Boeddhistiese, Katolieke, Confucius, Hindoe, Islamitiese en Joodse tradisies) geestelike perspektiewe gestel het (IBC 2004; Ten Have \& Jean 2009:31; Veatch 2012, par. 189). Met betrekking tot die godsdienstige gesprek maak Ten Have en Jean (2009:31), wat deel van die ontwikkeling en opstel van die deklarasie uitgemaak het, die volgende opmerking:

2 Die IBC is ' $n$ permanente liggaam van 36 kundiges uit verskillende dissiplines, lande en kulture, wat in 1993 tot stand gebring is deur UNESCO met die doel om die direkteur-generaal van UNESCO te adviseer (Ten Have \& Jean, 2009:21). 
One lesson from the presentations and discussions was that although there are differing moral views common values can be identified.

Neem hiermee saam in ag dat die algemene vergadering van UNESCO bestaande uit verteenwoordigers van 191 lidlande eenparig die Universele Deklarasie van menseregte en bio-etiek op 19 Oktober 2005 in Parys goedgekeur het (Andorno 2007:150; Ten Have 2008:31). Dit is duidelik dat die godsdienstige en politieke wêreld meen dat baat as daad binne die gesondheidsomgewing 'n besliste plig is en dus 'n "common value" van die mensdom vir die mensdom is.

Waarom neem etiese filosowe asook die UDMB "common morality" as hulle primêre bron of fundering, en nie 'n abstrakte etiese teorie nie? Douma (1997:83) beantwoord hierdie vraag deur daarop te wys dat beginsels en norme wat uit die een of ander etiese teorie gevorm is, meer aanvegbaar is as norme in die algemene moraal. Algemene moraliteit het 'n gemene deler. Daar bestaan in die algemeen groter sosiale konsensus oor beginsels en norme wat aan die algemene moraal ontleen is. Teorieë staan in die algemeen teenoor mekaar ten opsigte van begronding, beredenering en metode.

' $n$ Ander baie belangrik rede volgens Beauchamp en Childress (2008:205-206) waarom baat ' $n$ plig is, word gevind in die gedagte van wederkerigheid (vgl. ook Douma 1997:89). In aansluiting by David Hume word van die standpunt uitgegaan dat die daad van baat 'n plig is omdat die agent in die een of ander vorm van die samelewing baat ontvang het, sal ontvang of op die punt staan om te ontvang. Dit is ondenkbaar om te aanvaar dat die mens grootliks vry is of jouself kan bevry van 'n dank verskuldig aan ouers, navorsers in medisyne, openbare gesondheid, opvoeders en sosiale instellings soos skole en universiteite. So word baat in wederkerigheid begrond.

\subsection{Samevatting}

Dit is duidelik dat die UDBM baat - as goeie daad teenoor die mens verstaan as ' $n$ universele reg en plig wat uitdrukking aan menswaardigheid gee. Daar is aangetoon dat dit die plig van die gesondheidswerker is om binne die gesondheidsomgewing goed te doen aan die persoon. Vervolgens sal nou oorgegaan word tot die Christelike beoordeling van baat as menseregtebeginsel. 


\section{BAAT AS CHRISTELIKE BEGINSEL}

\subsection{Begronding}

Dat die beginsel van baat deur die UDBM in algemene moraliteit (common morality) begrond is, is reeds uitgewys, wat beteken dat feitlik alle mense saamstem dat baat 'n definitiewe plig is, soos feitlik alle mense erken dat moord oneties is. Dit is nie nodig dat die gelowige nie op sy gemaak voel hiermee voel nie omdat die Skrif nie vreemd staan teenoor die vrug van die rede en insluiting van die natuurwet (lex naturalis) nie. Daar bestaan nog baie gesonde verstand ("common sense") en gemeenskaplike redelikheid (Douma 1997:56). Die natuurwet beteken dat die mens, kragtens sy geskapenheid na die beeld van God, oor 'n rasionele vermoë beskik wat die natuurlike besef en formulering van wat reg en verkeerd is (Gen. 1:27; Rom. 2:14), insluit. Laasgenoemde kom daarop neer dat 'n bepaalde globale organisasie soos UNESCO etiese insigte kan openbaar wat deur die Christelike geloof ondersteun kan word.

Tog is sommige etici van oordeel dat die baat as plig meer fundamenteel as die rede begrond moet word (Cullity 2008:20). Is baat 'n sekulêre beginsel of kan dit in die lig van die gereformeerde tradisie Christelik begrond word? Waarom is dit vir die Gereformeerde etiek belangrik om die reg en beginsel van baat te begrond? Die eerste rede is dat begronding van 'n etiese beginsel 'n hartlike belydenis uitmaak van wat Christene glo (Østnor et al. 1995:9; Hollenbach 2003; Waldron 2010:233-234). Tweedens, al word die bestaan van die natuurwet (rede, ervaring en gewete) erken, moet bely word dat natuurlike kennis soms verkeerd of onvolledig kan wees (Ef. 4:17-24; Rom. 1:19ff; 3:19ff) en daarom aan die Skrif getoets, aangevul of gekorrigeer moet word (Østnor et al. 1995:24-25). In die derde plek is die vraag: ondersteun die Christelike etiek, per definisie God, die reg van baat soos dit binne die UDBM verstaan word? (Kung 2011 par. 2674-2676). Binne die Gereformeerde paradigma begin alle etiek by die drie-enige God en nie by die mens nie (Ross 2011:335) en is daarom deontologies van aard. God drie-enig is die primêre fondasie van alles wat eties is.

Om uitvoering aan laasgenoemde te gee, dus om baat Christelik te begrond, moet artikel 4 van die UDBM Christelik-eties beoordeel word. Vorster (2004:67) sê in die verband:

The ethical evaluation of the values subjacent to the modern bills of human rights in constitutions as well as the values emanating from these bills of human rights need to be done from a sound and clearly defined Christian ethical paradigm. 
In die beoordeling van die mens se reg op baat moet baie versigtig met die Bybel te werk gegaan word. In die verlede is die Bybel op verskeie maniere misbruik (2 Pet 3:16), maar misbruik sluit nie die goeie gebruik van die Bybel uit nie (Douma 1997:39). Daar moet gewaak word teen Biblistiese gebruik van die Bybel. Hoe vind begronding plaas? Vorster (2004:90-91) meen dat menseregte in die lig van sekere temas en basiese beginsels beoordeel moet word.

It is the Bible as a whole that is the normative source for knowledge. The use of the Bible in ethics presupposes a hermeneutical task, a work of interpretation in which the details are seen in the light of the totality and the periphery is differentiated from the center - the message about Jesus Christ, his person, work and will (Østnor et al. 1995:24).

Ook Douma (1997:41) sluit aan by die gedagte van temas wanneer hy temas as koördinate aandui wat rigtinggewend is in die beoordeling van moderne etiese vraagstukke.

Daar sal nou oorgegaan word tot die beoordeling van baat in die lig van die volgende temas: skepping, verlossing en eskatologie (vgl. ook Douma 1997:44; Vorster 2004:79-80).

\subsection{Beoordeling}

\subsubsection{Skeppingsperspektief}

Goedheid speel ' $n$ besonder sentrale rol in die skeppingsverhaal (Ross, 2011:334). Die skeppingsverhaal vertel dat die goeie God alles goed geskape het, ook die mens. Van besondere belang is dat God die mens as sy beeld geskape het, terwyl die diere volgens hulle soort geskape is (Douma 1997:44). Die mees onderskeidende kenmerk van die mens word gevind in die feit dat hulle na die beeld van God geskape is (Gen. 1:27; Vorster 2004:91-92). Die Katolieke biskoppe van Amerika is ook van oordeel dat die beeld van die mens 'n besliste relevansie binne die bioetiese diskoers het (Ethical And Religious Directives For Catholic Health Care Services 2009:5; vgl. Frame, 1988:14).

Wat is die implikasie van die beeldskap van die mens in die etiese beoordeling van baat as beginsel? Die eerste perspektief is dat die mens na die beeld van die goeie God geskape is. God is die summum bonum (Ross, 2011:334), daarom doen Hy die goeie. Telkens wys die Bybel op die goedheid van God (Ps. 31:20), wat aan alle mense goed doen en medelye betoon (Ps. 145:7,9). God word vir sy goedheid geprys (Ps. 106,107), terwyl hierdie eienskap van God in besonder deur Christus bevestig word (Mark 
10:18, Ross 2011:334). Gesien vanuit 'n Gereformeerde standpunt word die mees sigbare voorbeeld van God se goedheid in Christus duidelik gevind. Hierdie eienskap van God het besondere etiese waarde as Holmes (1995:412-213) die volgende sê:

That God is the highest good for all creation has implications for human goodness. God's goodness is the norm, so a person is good in so far as he or she is like God in benevolence and loving kindness... Toe be good is to be like God, to image his goodness in both the inner reality and the outward activities of one's life.

Om beeld van God te wees beteken om dit wat goed is, te doen.

To do good we direct our actions beneficial ends. Beneficence and benevolence are teleological concepts; beneficence is a teleological principle for making ethical decisions (Holmes 1995:413).

Thomas van Aquino het uitgegaan van die standpunt dat die verbeelding van die goedheid van God die primêre beginsel is waaruit alle ander beginsels vloei. Die eerste beginsel van die morele natururwet is om goed te doen en niemand kwaad aan te doen nie. Die utilitarisme het die beginsel van baat oorgeneem in die reël dat goed en kwaad gebalanseer word deur baat te maksimaliseer en die kwaad te minimaliseer.

In this way, the biblical conception of goodness continues to influence Western ethical thinking; whether or not contemporary thinkers recognize it. (Holmes, 1995:413).

As tweede perspektief kan daarop gewys word dat die feit dat God die mens na sy beeld geskape het, die mens sonder twyfel in 'n besondere verband met God bring (Vorster 2007). Beeld-wees van God impliseer dat die mens onbepaalde waarde het. Vorster (2011, vgl. ook Waldron 2010), na deeglike bespreking van die mens as beeld van God, som die implikasie van die imago Dei vir die teologiese antropologie soos volg op:

Because God created the human after his image the human possesses an inherent dignity that animals do not enjoy...all human beings possess an equal worth.

Die besondere status van die mens of menswaardigheid word ook Christologies begrond. Die verkondiging dat die Seun van God die menslike natuur aangeneem het, en as mens heerlikheid ( $\delta$ ó $\xi \alpha \nu)$ vertoon, bevestig die waardigheid van die mens (Joh. 1:14). Die duidelike implikasie van bogenoemde beredenering vir die verstaan van menswaardigheid stel Vorster (2007; vgl. ook Sulmasy 2008): 
Dignity is a status that God awards the human, and therefore the human should live according to his status and treat others according to their status.

Volgens Østnor et al. $(1995: 12,30)$ impliseer die beeldskap van die mens dat baat beslis uitdrukking gee aan die waardigheid van die mens. Gesien vanuit die skeppingsperspektief is Pellegrino (2009:101) korrek as hy beweer dat inherente waardigheid die plig genereer om aan die siek mens niks anders as goed te doen nie; daarom is die UDBM korrek deur artikel 3 artikel 4 vooraf te laat gaan.

As derde perspektief word gestel dat na die skepping van die mens as beeld van God, ' $n$ opdrag aan die mens gegee is waarin die skepsel die opdrag gegee is om oor die aarde te regeer (Gen. 1:28), en dit staan bekend as die kultuuropdrag. Vorster in sy boek Ethical perspectives on human rights bespreek die moontlike betekenis van die kultuurmandaat in hierdie verband en stel die volgende vraag in die lig van Gen. 1:28:

The ethical question which arises from this is: How does man handle life that God gave....and the life of human beings (2004:82)

en dan beantwoord hy hierdie vraag soos volg: "Life as God's creation must indeed be protected and unfurled". In hierdie sin verstaan Vorster regeer as 'n opdrag wat eis dat toegesien moet word dat menslike lewe ontvou. Vorster (2004:82) maak dan die opmerking dat die beginsel of opdrag om die ontvouing of ontplooiing (unfurl) van die lewe te bevorder in die mediese etiek van die uiterste belang is. Binne die gesondheidsorg het die gesondheidswerker die plig om so op tree dat sy handeling sal bydra tot die bevordering van die gesondheid en algemene welstand van die individu en op so 'n wyse die pasiënt sal help ten opsigte van die normale voortgaan en ontplooiing van sy lewe.

In verdere aansluiting by die gedagte dat die mens op ' $n$ wonderbaarlike wyse deur God geskape is (Gen. 1:27; Ps. 139, Job 12:10), word in die Skrif - as vierde perspektief - 'n band tussen beeldskap en die sesde gebod gevind (Douma, 1997:53). Die mens mag nie wederregtelik doodgemaak word nie (Eks. 20:13), omdat dit 'n vergryp is aan die mens wat na die beeld van God geskape is (Gen. 9:6; De Bruyn 1993:134). Dit moet egter in gedagte gehou word dat die sesde gebod ook in sy positiewe betekenis verstaan moet word. Immers is dít hoe Christus self die sesde gebod interpreteer (Matt. 5:23). De Bruyn (1993:139-140) som die positiewe betekenis van die sesde gebod op as die betoon van baat aan die ander mens en stel dit soos volg (vgl. ook Østnor et al 1995:32): 
Daarom moet hy by die sesde gebod, naas die verbod wat dit behels ook die gebod sien wat daarin opgesluit lê en daaraan uitvoering gee... Op grond van sy naasteliefde moet die gelowige alles wat sy medemens kan benadeel of skade berokken sover moontlik voorkom (Eks. 23:5) en positief sy belange probeer bevorder en binne sy vermoë doen wat vir sy naaste die beste is.

Ook Vorster (2004:98) sien die positiewe betekenis van die sesde gebod as hy aanvoer dat die gebod die ontvouing van menslike lewe wil bevorder. "Vir sy naaste die beste" dui ook op die feit dat baat gemaksimaliseer moet word, wat beteken dat die mees moontlike goed binne die gegewe situasie aan die ander mens gedoen moet word. Heyns (1970:188) sluit hierby aan as hy uit die sesde gebod aflei dat die mens "alles moet doen vir die bevordering van die lewe", en verbind hierdie oproep aan die menslike wil tot gesondheid.

Uit bogenoemde bespreking kan die reg en etiese beginsel van baat Christelik begrond word.

\subsubsection{Verlossingsperspektief}

As 'n resultaat van die herskeppingswerk van Christus deur regverdigmaking, versoening en die aanneming as kind van God, het die mens in 'n nuwe verhouding met God te staan gekom (2 Kor. 5:1720; Kol. 3; Vorster, 2004:82,136). As eerste perspektief stel laasgenoemde teksgedeeltes duidelik wat die vrug van die herskepping is, naamlik dat die Christen 'n nuwe mens of skepsel is. Hierdie herskepping bring 'n nuwe lewe wat nie alleen 'n nuwe verhouding met God impliseer nie, maar ook met die ander mens. Volgens König (2001:254) beteken hierdie nuwe verhouding met God en jou naaste 'n nuwe waardestelsel. Douma (1997:48) tipeer Jesus se herskeppingswerk as Christus medicus omdat Hy deur die herskepping van die mens en skepping genesing van die sonde en verval bewerk het. Christus medicus moet deur die kerk nagevolg word en moet elke gelowige inspireer (Ethical And Religious Directives For Catholic Health Care Services 2009:4).

Wat is die implikasie van die feit dat die mens 'n nuwe skepsel is in die etiese beoordeling van baat as beginsel? Die gevolg van Christus medicus in die lewe van die gelowige is 'n lewe van liefde, as Vorster (2004:82) skryf: "Life in re-creational perspective emphasises Christen love as guideline for ethical behaviour". Douma (1997:53-54), in sy bespreking van bio-etiese norme, verstaan Christelike liefde as baat en stel dit soos volg:

Wel-doen vraagt meer dan geen-kwaad-doen, in de zin van "geen schade berokkenen". Het welzijn van de patient moet positief 
bevorderd worden. Dit ligt dicht tegen het betonen van liefde aan (vgl ook Ethical And Religious Directives For Catholic Health Care Services 2009:3)

In aansluiting by die gedagte van die verandering deur Christus word as tweede perspektief ook gestel dat die veranderde mens hom of haar ook sien as die objek van God en Christus se liefde (1 Joh 4:9-10; Østnor et al. 1995:15-16). Die feit dat die mens die objek van liefde is, kan nie anders as om die gelowige te dwing om ook sy naaste as objekte van liefde te beskou nie (1 Joh 4:11,19). Mense moet liefhê soos God hulle liefgehad het. Volgens Østnor et al $(1995: 16,21)$ bestaan daar 'n direkte verband tussen Christelike liefde en baat as hulle skryf (vgl. ook Frankema 1963:44³):

Luther often summed up the content of neighbourly love in two words: beneficence and suffering ... [and] ... neigbourly love as beneficence has the effect that the Christian will make use of the worldly orders to the benefit of the other." In the New Testament this connection is expressed by the double command of love... (Matt. 23:37, 39).

Douma (1997:89) sluit by bogenoemde aan:

Het is niet zozeer het weldoen van andere mensen, dat onze reactie van weldoen moet uitlokken, maar Gods liefde die ons in Christus bewezen is.

In die lig van bogenoemde kan beweer word dat die nuwe mens 'n veranderde mens is wat sy medemens liefhet deur goeie dinge aan hom te doen.

'n Verdere tema binne die verlossingsperspektief, as derde perspektief, is die feit dat die nuwe mens, binne die gesondheidsomgewing, deur die barmhartigheid en in besonder die barmhartigheid van Christus gemotiveer word om baat te betoon (Ethical And Religious Directives For Catholic Health Care Services 2009:3). Douma (1997:41) stel dit soos volg:

Wat die motivatie betref, altyd heeft de christelijke barmhartigheid (of liefde) mense bewongen om hulp te verlenen aan zieken en gebrekkige mensen. Daarvoor biedt de bijbel het grote voorbeeld in Jezus Christus zelf. Hij word deur de aanblik van zieken en ellendigen bewogen om zijn genezende kracht aan te wenden.

3 "The clearest and most plausible view, in my opinion, is to identify the law of love with what I have called the principle of benevolence, that is, of doing good...". 
Uit bostaande aanhaling is dit duidelik dat die deug van barmhartigheid nie anders kan as om tot baat te lei nie. Die beginsel van baat word verstaan as positiewe hulp en, waar moontlik, genesing aan die persoon binne die gesondheidsomgewing. Volgens die Gereformeerde etikus Douma kan die gelykenis van die barmhartige Samaritaan (Luk. 10:25-37) geïnterpreteer word as 'n verpligting tot barmhartigheid in die vorm van definitiewe hulp aan die onwel mens. Die Samaritaan word deur barmhartigheid beweeg (v. 33) tot positiewe baat - deur nie verby te stap nie - wat geheel en al (maksimaal) die onwel persoon se wonde verbind en wyn en olie daarop gegooi het waarna hy hom na 'n veilige plek geneem het. Uit die optrede van die Samaritaan kan myns insiens ook die beginsel van die maksimalisering van baat afgelei word, wat beteken dat binne 'n gegewe situasie die meeste moontlik goed aan die mens gedoen moet word. Beauchamp en Childress (2009:198) is van mening dat versorging as baat binne die mediese konteks uit hierdie gelykenis afgelei kan word. Dat baat ook 'n plig is, kan afgelei word uit die feit dat Christus aan die ryk man die opdrag gee: "Gaan en doen jy net so" (v. 37). Die konferensie van Katolieke biskoppe in Amerika is van mening dat die kerk as voorbeeld moet dien van die baat in die gelykenis (Ethical And Religious Directives For Catholic Health Care Services 2009:4).

Binne die menseregte-diskoers word gevra of die reg op baat nie die Christelike gedagte van barmhartigheid opgehef het nie? Immers, baat het 'n reg geword. Barmhartigheid is nou vervang deur 'n kontrak tussen die outonome pasiënt en die mediese praktisyn. Hierteenoor kan geantwoord word dat reg en barmhartigheid nie teenoor mekaar gestel moet word nie. Reg en plig is korrelatiewe begrippe, en dit moet in gedagte gehou word. Die versorgde het 'n reg op baat, terwyl die versorger die plig tot baat het (Frankena 1963:45). Hierdie plig word begrond en gemotiveer vanuit die Christelike oproep tot barmhartigheid. Douma (1997:43) stel dit soos volg:

Gesondheidszorg is gelukkig ook een recht geworden, toegankelijk voor iedereen...Maar wel zal de zorgverlener in Christus het inspirirend voorbeeld voor zijn beroepsbeoefening kunnen vinden.

Douma (1997:49) is verder van oortuiging, as vierde perspektief, dat die beginsel van baat op vier maniere direk ook met Christus medicus in verband gebring kan word. Die eerste is dat Christus op 'n positiewe, duidelike manier baat aan die onwel mens betoon het deur genesing en hieruit word die reg verkry om baat te ontvang en baat te gee. So het $\mathrm{Hy}$ deur positiewe baat die koors van Petrus se skoonmoeder bestraf (Ethical And Religious Directives For Catholic Health Care Services 2009:3-4; Matt. 9:35; Luk 4:39). In hierdie sin kan die volgende beginsels van baat 
(Beauchamp \& Childress 2009:13,199; Pellegrino 2009:102) in Christus begrond word:

- Beskerm en verdedig die regte van die ander mens.

- Voorkom skade aan die ander mens.

- Verwyder toestande wat die ander mens skade sal aandoen (genesing).

In die Christelike geskiedenis het individue die pynverligtende en verdowende middels geweier omdat Christus dit aan die kruis afgewys het. In die tweede plek kan eerder beweer word, omdat Christus medicus die lydingsbeker tot die laaste druppel uitgedrink het - in volle bewussyn terwyl Hy geweier het om sy lyding te verdoof (Matt 27:34) het die mens nie nodig om die las van pyn te dra nie, maar moet eerder verlig word as 'n daad van baat (vgl. Beauchamp 2008:5; Beauchamp \& Childress 2009:13,199).

Derdens is dit van groot betekenis dat Christus besondere aandag geskenk het aan die mense wat in die Nuwe Testamentiese tyd gesondheidsgewys as minderwaardig beskou is, naamlik besetenes, maansiekes, verlamdes, melaatses, blindes en dowes. In die lig van die feit dat Christus hierdie mense genees het, moet hulp aan die mens met gestremdheid as beginsel van baat afgelei word (Beauchamp \& Childress 2009:13,199).

Vierdens skenk Christus aan die totale mens aandag. Daar is reeds op gewys dat baat nie slegs tot die fisiese aspek van gesondheid beperk mag word nie, maar dat dit ook die psigologie en sosiale aspekte van gesondheid insluit (vgl. ook Heyns 1970:188). Die Ethical And Religious Directives For Catholic Health Care Services (2009:3) skryf in die verband "Jesus' healing mission went further than caring for physical affliction" en wys daarop dat Christus fisiese, psigologiese en spirituele gesondheid gesoek het (Joh. 6:35; 11:25-27). Hy het immers gekom sodat hulle die lewe in oorvloed mag hê (Joh. 10:10).

'n Belangrike onderwerp wat Douma (1997:54) aansny in samehang met die belydenis van die veranderde mens, as vyfde perspektief, binne die konteks van die bio-etiek, is die opdrag rakende die opgee van die eie belang (1 Kor. 13:5). Die Christelike etiek ken nie werklik iets soos buitengewoon goeie werke nie. Binne die gesondheidsorg word dit van die versorger verwag om hom of haar te verloon of op te offer (Joh. 15:13; Frame 1988:16). Hierdie gerigheid op die ander word deur König (2010:175) gedefinieer as 'n gee-liefde. Gee-liefde is die teenoorgestelde van erosliefde wat gerig is op die voordeel wat die ander uiteindelik vir die eie sal hê. Gee-liefde is ' $n$ beweging weg van die persoon na 'n ander terwille van ander. Dit is om te offer tot voordeel van die ander, al is dit tot eie nadeel. So het Christus as beeld van God liefgehad. Gee-liefde word begrond in 
Skrifgedeeltes soos 1 Kor. 10:24, 33; 11:1 en Fil. 2:4. In dié sin is Douma korrek as hy sê "De christelike liefde vraagt meer dan verplicht is, want zij vraagt om gerichtheid op de ander en niet op zichzelf". 'n Belangrike teks wat König in hierdie verband noem, en wat die belangrikheid van die ander, en baat in die besonder, verbind, is Rom. 15:2 wat soos volg lees: "elkeen van ons moet aan ons naaste dink en aan dit wat vir hom goed is".

Ten slotte, as sesde perspektief, kan ook daarop gewys word dat die norm wat in Matt 7:12 gestel word, 'n belangrike reël is wat deur die nuwe mens teenoor alle mense uitgevoer word (Gal. 6:10). Volgens Douma (1997:55) is die Goue reël binne die bio-etiese diskoers om twee redes van besondere belang. In die eerste plek sou hierdie reël as die etiese begronding van menseregte beskou kon word. Die mens besit die vermoë van selfbewussyn en self-transendensie. Volgens Hollenbach (2003:246247) beteken dit dat die mens nie net tot hom- of haarself beperk is nie, maar die vermoë besit om (jou eie) menslikheid in die ander mens te ervaar, en dit plaas 'n plig om jou: "As jy wil hê die ander mens moet jou regverdig behandel, moet jy die ander mens op dieselfde wyse behandel". In hierdie sin kan artikel 4 van die UDMB in Matt. 7:12 begrond word in die sin van "As jy wil hê dat mense aan jou baat moet betoon, wanneer jy siek is, moet jy aan hulle baat betoon wanneer hulle siek is". Tweedens word die Goue reël as 'n baie effektiewe ontdekker van die kwaad beskou. In dié verband wys Armstrong (2009:33,85-86) daarop dat die mens diep in sy hart moet inkyk en ontdek wat vir hom pynlik sal wees en dan weier om dit aan die ander mens te doen. In hierdie sin sal dit vir die meeste mense pyn veroorsaak om binne die konteks van gesondheid nie baat te ontvang nie en daarom is baat ' $n$ plig wat die medemens opgelê word (vgl. ook König, 2010:177,179).

Uit die bespreking kan die reg op en etiese beginsel van baat sonder twyfel Christelik begrond word.

\subsubsection{Eskatologiese perspektief}

Pellegrino (2009:105) maak die volgende opmerking: "Article 4, like all ethical principles or action guidelines, must be actualized through individual human beings".

Wat is die implikasie van die eskatologies perspektief in die etiese beoordeling van baat as beginsel? Die beginsel van baat word nie net in die skepping en verlossing gefundeer nie, maar teologies afgerond deur eskatologiese of pneumatologiese begronding - as eerste perspektief - in die vrug van die Gees. Die Gees is 'n eskatologiese gawe (Hand. 2:17). Alhoewel liefde die gevolg is van die herskeppingswerk van Christus, word liefde ook deur die Gees van God in die praktyk van die lewe verwesenlik 
(Rom. 5:5, Gal. 5:6) as die eerste vrug van die Gees (Gal. 5:22; Fung, 1988:262). Inderdaad lei die Gees die mens tot volle medemenslikheid (Heyns 1982:104), wat baat impliseer.

Volgens Augustinus en Luther word liefde eerste op die lys geplaas omdat dit in werklikheid die enigste Christelike deug is (Simpson 2011:319). Al die ander nege konkrete dade (deugde) in die Pauliniese lys kan beskou word as spesifieke uitdrukkings van liefde wat gerig is op die ander mens in gemeenskap (Ladd 1974:491,522). Die werk van die Gees is op die konkrete dade van die gelowige gerig; daarom word die vrug van die Gees beskryf ooreenkomstig 'n etiese gedragskode (Lategan 1984:326). H.D. Betz, soos aangehaal in Fung, oordeel soos volg: "the nine concepts should be taken as 'benefits' which were given as or together with the Spirit". Een van die besondere etiese karaktereienskappe wat die Gees in die lewe van die gelowige voortbring, is baat of goed doen (Gal. 5:22; Fung 1988:262). Dit beteken dat die Gees "Article 4... actualize through individual human beings".

As tweede perspektief kan daarop gewys word dat dankbaarheid en baat met mekaar verbind word. Uit bogenoemde bespreking het dit duidelik geword dat die Gees in die mens werk, wat ook impliseer dat dankbaarheid deur die Gees bewerk word. Dankbaarheid was nog altyd een van die sentrale begrippe in die Gereformeerde teologie. Reeds is daarop gewys dat morele filosowe die toedeel van baat begrond in die standpunt van wederkerige dank aan die gemeenskap, naamlik omdat die gemeenskap baat aan my betoon het, sal ek baat betoon. Die gelowige is teenoor God dankbaar omdat $\mathrm{Hy}$ in Jesus Homself gegee het en daarom is dankbaarheid 'n geloofsdaad wat antwoord op die genade. König (2010:180-184) wys daarop dat dankbaarheid primêr teenoor God betoon word maar wat insgelyks teenoor die medemens betoon word. Dankbaarheid beteken om genadig teenoor die ander mens te wees. In dié sin sou dit nie teen die Christelike etiek wees om baat in wederkerige dank te fundeer nie. Omdat ' $n$ mens dankbaar is vir God se genade asook vir die feit dat die gemeenskap aan jou goed gedoen het, moet jy baat betoon aan jou medemens as 'n vorm van genade. In hierdie sin kan baat verstaan word as vrugte van dankbaarheid (HK v/a 64) en 'n vrug van die Gees (Gal. 5).

Die herskeppingswerk van Christus sal eers finaal afgehandel wees wanneer die nuwe hemel en nuwe aarde aanbreek. Intussen lewe die mens in 'n gebroke realiteit wat net gedeeltelik leefbaar gemaak kan word, omdat die mens nooit die volle goed op aarde sal verwesenlik nie. Die Christen mag weet en hoop dat met die volheid van tyd alle gebrokenheid beëindig gaan word. Vorster meen egter dat die Christelike hoop - as derde perspektief 
- as eskatologiese gawe nie alleen met betrekking tot die toekoms verstaan moet word nie; dit het ook betekenis vir die nou en die tema van menseregte (vgl. ook Gill 1995:455). Hy maak die volgende opmerking:

Hope is especially important for ethics in the broken dispensation in which man now lives. Hope brings a life of expectation that God will not leave injustice and pain as it is. He brings movement and change and humankind can hope for change in its suffering. Ethical behaviour must keep this hope alive. Like love is a commandment of the new person, the giving of hope as an ethical act is also a cardinal commandment in the Christian ethics. Ethical decision making and behaviour must, in a seemingly hopeless situation or in a spirit of hopelessness, be the key to hope in the working hand of God. In this way hope must be kept alive for the poor, the suppressed and the wronged. Christian ethical behaviour must bring hope for people in despair (vgl. Vorster 2004:83).

Hoop gee sin in en aan die lewe. Mense wat hoop, kan die haglikste omstandighede trotseer (König 2001:118). In dié sin moet die beginsel van baat ook as Christelik aanvaar word, omdat dit vir mense binne slegte gesondheidsomstandighede die hoop kan skep dat daar inderdaad iets soos goeie gesondheidsorg bestaan, en dat dit mettertyd geïmplementeer en afgedwing moet word. Van Niekerk Benatar (2011:141) wys op 'n verslag deur die Ethics Institute of South Africa wat bevind het dat twee van Suid-Afrika se grootste en bekendste hospitale, naamlik die Chris Hani Baragwanath en Universitas hospitaal, se toestande en praktyke nie menseregte bevorder het nie. Beginsel 4 van die UDBM moet gunstig beskou word omdat dit hoop gee aan baie landsburgers. Die UDBM kan aan burgers van Suid-Afrika besondere hoop gee.

Uit bogenoemde diskussie kan die reg en etiese beginsel van baat Christelik verdedig word.

\subsection{Samevatting}

Pellegrino (2009:106) in sy kommentaar op artikel 4 van die UDBM oordeel die volgende:

Benevolence is a character trait that habitually disposes one to do good. Beneficence, on the other hand, is the act that enables one to do good. This point, and the distinction it encompasses, is crucial to the implementation of Article 4. It speaks not only to the principle but to the kind of person required to apply the principle optimally. 
Die Christen as veranderde mens in Christus is "the kind of person", wat as beeld van God deur die Gees geïnspireer word om binne die gesondheidsomgewing goed te doen aan alle mense.

\section{SLOT}

Die hooftaak van Christene is om by te dra tot die oprigting en instandhouding van 'n demokratiese samelewing. Hulle moet hulle beskikbare kapasiteit gebruik om sover moontlik die samelewing volgens die beginsels baat en naasteliefde te organiseer (Østnor et al 1995:20). Frame (1988:14) vat die Bybelse begronding vir baat soos volg saam:

The Biblical ethic is not one of merely avoiding evil; it is one of pursuing good. Therefore we speak of the "principle of beneficence": we have a duty to help those in need, just as the Good Samaritan helped the man who was injured on the road.

Artikel 4 van UDBM is duidelik, presies en onomwonde ontwikkel om die inherente reg op baat en menswaardigheid van elke mens in die gesondheidsomgewing te beskerm (Pellegrino, 2009:108). Tog kan uit 'n Christelik-etiese hoek geredeneer word dat hierdie artikel nie net die reg beskerm nie maar dat, waar baat as reg uitgevoer word, dit aanleiding gee tot die eksistensiële beleef van menswaardigheid (Ethical And Religious Directives For Catholic Health Care Services 2009:11):

The care provided assists those in need to experience their own dignity and value, especially when these are obscured by the burdens of illness or the anxiety of imminent death

Vanuit ' $n$ Christelike sienswyse kan die etiese beginsel van baat, soos uiteengesit in artikel 4 van die UDBM, ondersteun word en kan Christene vrede hê met hierdie mensereg.

\section{BIBLIOGRAFIE}

Andorno, R. 2007. Global bioethics at UNESCO: in defense of the Universal Declaration on Bioethics and Human Rights. Journal of Medical Ethics 33:150-154.

Armstrong, $\mathrm{K}$.

2009. The case for God. What religion really means. London: The Bodley Head 
Beauchamp, T.L.

2008. The "Four principles" approach to health care ethics. In: R.E. Ashcroft, A. Dawson, H. Draper \& J.R. McMillan (eds.) Principles of health care ethics. Second edition. (Engeland: Johan Wiley \& Sons), pp. 3-10.

Beauchamp, T.L. \& Childress. J.F. 2009. Principles of biomedical ethics. Sixth Edition. Oxford: Oxford University Press.

Cullity, G.

2008. Beneficence. In: R.E. Ashcroft, A.Dawson, H. Draper \& J.R. McMillan (eds.). Principles of health care ethics. Second edition, (Engeland: Johan Wiley \& Sons). pp. 19-26.

De BRuYn, P.J. 1993. Die tien gebooie. Midrand: Varia uitgewers.

Ethical And Religious Directives For Catholic Health Care Services. 2009. United States conference of Catholic bishops. Fifth Edition. Washington: USCCB Publishing.

FrankenA, W.K.

1963. Ethics. Foundations of philosophy series. London: Prentice-Hall International.

FRAME, J.M.

1988. Medical ethics. Principles, persons, and problems. Phillipsburg, New Jersey: Presbyterian and Reformed Publishing Company.

FUNG. R.Y.K.

1988. The epistle to the Galatians. Grand Rapids, Mich.: Wm.B Eerdmans.

GILL, D.W.

1995. Hope. In: D.J. Atkinson \& D.H. Field (eds.), New dictionary of Christian ethics and pastoral theology. (Downers Grove, III.: Intervarsity Press), pp. 455-457.

HeYns, J.A.

1970. Die nuwe mens onderweg. Oor die tiengebooie. Kaapstand: Tafelberg-Uitgewers.

1982. Teologiese etiek. Deel 1. Pretoria: NG Kerkboekhandel Transvaal.

Holmes, A.F.

1995. Goodness. In: D.J. Atkinson. \& D.H. Field (eds.), New dictionary of Christian ethics and pastoral theology (Downers Grove, III.: Intervarsity Press) .pp. 619-621.

Hollenbach, D.

2003. The global face of public faith. Washington, D.C.: Georgetown University Press. 
IBC.

2004. Eleventh session of the International Bioethics Committee of UNESCO. UNESCO, Paris, 23-24 August 2004. [Online.] Retrieved from http://portal. unesco.org/shs/en/files/7495/11103874181ReportCIB11_en.pdf/ReportCIB11_ en.pdf (2008, 1 February).

KöNIG, A.

2001. Steultelbegrippe van die Christelike geloof. Fokus op die 300 vrae wat mense die meeste vra. 'n Verwysingsgids vir elke huis. Kaapstad: Lux Verbi.BM.

2010. Alle paaie lei na Jesus. Hoe die groot tema van die Bybel op Jesus uitloop. Vereeniging: Christelike Uitgewersmaatskappy.

LADD, G.E.

1974. A theology of the New Testament. Grand Rapids, Mich.: Wm.B Eerdmans.

LATEGAN, B.C.

1984. Handleiding by die Nuwe Testament. V. Die Pauliniese briewe: Inleiding en teologie. Pretoria: N.G. Kerkboekhandel.

Østnor, L., HallamaA, J., Andersen, S., Buörnssom, B., Nilsson, G. \& Thunberg, L. 1995. The Lutheran approach to bioethics. In: V. Mortensen (ed.), Life and death. Moral implications of biotechnology. (Geneva: WCC Publications). pp. 9-34.

Pellegrino, E.D.

2009. Article 4: Benefit and harm. In: H. Ten Have \& M.S. Jean (eds.), The UNESCO universal declaration on bioethics and human rights. Background, principles and application (Paris: United Nations Educational, Scientific and Cultural Organization). pp. 99-109.

Ross, C.R.

2011. Goodness. In: J.B. Green (ed.), Dictionary of Scripture and ethics (Grand Rapids: Baker Publishing Group). pp. 334-335.

Simpson, G.M.

2011. Fruit of the Spirit. In: J.B. Green (ed.) Dictionary of Scripture and ethics (Grand Rapids: Baker Publishing Group), pp. 334-335.

Ten Have, H.

2008. Towards global bioethics: The UNESCO universal declaration on bioethics and human rights. In: V. Launis \& J. Räikkä (eds.), Genetic democracy. Philosophical perspectives (Dordrecht, Heidelberg, New York, London: Springer Science+Business, Media B.V.), pp. 31-42.

2011. Bioethiek zonder grenzen. Mondialisering van gezondheid, ethiek en wetenschap. Antwerpen: Valkhof Pers. Maklu-Distribusie.

Ten Have, H. \& Jean, M.S.

2009. Chapter 1. Introduction. In: H. Ten Have \& M.S. Jean (eds.), The UNESCO universal declaration on bioethics and human rights. Background, principles and application (Paris: United Nations Educational, Scientific and Cultural Organization), pp. 17-56. 


\section{UNESCO.}

2005. Records of the general onference 33rd session Paris, 3-21 October 2005 Volume 1 Resolutions United Nations Educational, Scientific and Cultural Organization. [Online.] Retrieved from: http://portal.unesco.org/en/ev.php-URL ID=28354\&URL_DO=DO_TOPIC\&URL_SECTION=201.html (2012, 14 June).

2006. Universal declaration on bioethics and human rights. [Online.] Retrieved from: http://unesdoc.unesco.org/images/0014/001461/146180E.pdf (2012, 14 June 2012).

2008. Bioethics core curriculum. Section 1: Syllabus ethics education programme sector for social and human sciences division of ethics of science and echnology. [Online.] Retrieved from: http://unesdoc.unesco.org/ images/0016/001636/163613e.pdf (2012, 14 June).

2008. Curriculum section 1: Syllabus ethics education programme.. Sector for social and human sciences. Division of ethics of science and technology. [Online.] Retrieved from: http://unesdoc.unesco.org/images/0016/ 001636/163613e.pdf (2012, 14 June).

2011. Bioethics core curriculum. Section 2: Study materials ethics education programme. Sector for social and human sciences. Division of ethics of science and technology. [Online.] Retrieved from: http://unesdoc.unesco.org/ images/0021/002109/210933e.pdf (2012,14 June )

Van Niekerk, A.A. \& Benatar, S.R. 2011. The social functions of bioethics in South-Africa. In: C. Myser (ed.) Bioethics around the globe, (Oxford: University Press), pp. 134-151.

VeATCH, R.M. 2012. Hippocratic, religious, and secular medical ethics: The points of conflict . [Kindle uitg.] Beskikbaar: http://www.amazon.com.

VORSTER, J.M.

2004. Ethical perspectives on human rights. Potchestroom: Potchefstroom Theological Publications.

2011. Menswaardigheid, versoening en vergiffenis. Potchefstroom: Potchefstroom Theological Publications.

Verhey, A.

2011. Bioethics. In: J.B. Green (ed.), Dictionary of Scripture and ethics (Grand Rapids, MI: Baker Publishing Group), pp. 95-101.

Keywords

Bio-ethics

Human rigths

UNESCO
Trefwoorde

Bio-etiek

Menseregte

UNESCO 